\title{
Analisis Kemampuan Berpikir Kritis Matematis Ditinjau dari Gaya Belajar Siswa Kelas VII SMP Negeri 1 Karawang Barat
}

\author{
Zahrani Dhea Safitri ${ }^{1}$, Asih Miatun ${ }^{2}$ \\ 1, 2 Program Studi Pendidikan Matematika, Fakultas Ilmu Pendidikan, Univesitas Muhammadiyah Prof. DR. Hamka, \\ J1.Tanah Merdeka, Jakarta, Indonesia \\ zahranidheas@gmail.com
}

\begin{abstract}
This study to aimed analyze students' mathematics critical thinking skills. The research method uses descriptive qualitative. The subject of this study were students with visual, auditorial, and kinaesthetic learning style, and selected using purposive sampling technique. Mathematical critical thinking skills tests and learning style questionnaires. Data were analysed using a reduction, data presentation, and conclusion drawing. The results showed; (1) students' mathematical critical thinking skills with visual learning style are very good, because they were able to fulfill the indicators, interpretation, analysis, evaluation, and inference; (2) the students' mathematical critical thinking ability with auditory learning style is good, because they were able to fulfill the indicators, analysis, evaluation, and inference, but the interpretation in explaining is still incomplete; and (3) students' mathematical critical thinking skills with kinesthetic learning style are quite good, because they weren't able have not been able to achieve indicators, analysis and evaluation. Students with visual learning styles have very good critical thinking skills, because they are better in explain mathematical concepts visually before solving math problems. In this case, students with auditory and kinaesthetic learning styles still have the potential to develop critical thinking skills.
\end{abstract}

Keywords: analysis, learning styles, critical thinking

\begin{abstract}
Abstrak
Penelitian ini bertujuan untuk menganalisis kemampuan berpikir kritis matematis siswa. Metode penelitian menggunakan deskriptif kualitatif. Subjek penelitian adalah siswa yang mempunyai gaya belajar auditorial, visual, serta kinestetik serta dipilih menggunakan teknik purposive sampling. Instrument pada penelitian ini menggunakan tes kemampuan berpikir kritis matematis dan angket gaya belajar. Analisis data yang dipergunakan ialah penyajian data, reduksi data, serta pengambilan kesimpulan. Teknik triangulasi dilakukan guna melakukan uji keabsahan data. Hasil penelitian membuktikan; (1) kemampuan berpikir kritis matematis siswa bergaya belajar visual sangat baik, karena mampu memenuhi indikator yakni, evaluasi, analisis, interpretasi, dan inferensi; (2) kemampuan berpikir kritis matematis siswa bergaya belajar auditorial baik, karena mampu memenuhi indikator yakni, evaluasi, analisis, dan inferensi, tetapi untuk interpretasi dalam menjelaskan masih kurang lengkap; dan (3) kemampuan berpikir kritis matematis siswa bergaya belajar kinestetik cukup baik, karena belum mampu mencapai indikator yaitu, analisis dan evaluasi. Siswa dengan gaya belajar visual mempunyai kategori sangat baik dalam kemampuan berpikir kritis matematis, karena lebih mampu mengjelaskan konsep matematika secara visual sebelum menyelesaikan permasalahan matematika. Dalam hal ini, siswa yang bergaya belajar auditorial dan kinestetik tetap mempunyai potensi mengembangkan kemampuan berpikir kritis matematis.
\end{abstract}

Kata Kunci: analisis, gaya belajar, kemampuan berpikir kritis

Copyright (c) 2021 Zahrani Dhea Safitri, Asih Miatun

$\square$ Corresponding author: Zahrani Dhea Safitri

Email Address: zahranidheas@gmail.com (Jl. Tanah Merdeka, Jakarta, Indonesia)

Received 06 July 2021, Accepted 21 July 2021, Published 04 November 2021

\section{PENDAHULUAN}

Berdasarkan peraturan kementerian kebudayaan dan pendidikan Nomor 20 tahun 2016 salah satu standar kompetensi lulusan yang perlu terpenuhi oleh siswa jenjang sekolah dasar dan menengah yaitu keterampilan/kemampuan berpikir kritis (Kemendikbud, 2016). Selain itu kemampuan berpikir kritis juga sebagai suatu kemampuan yang harus dimiliki di abad ke 21 ini (Basri et al., 2019; Harjo et al., 2019). Hal ini menjadi fokus penting bagi pelaksanaan pendidikan di sekolah menengah khususnya di sekolah menengah pertama. Kowiyah (2016) menjelaskan bahwa, matematika diberikan di jenjang 
pendidikan menengah maupun dasar tujuannya untuk mempersiapkan peserta didik supaya mampu dalam berpikir matematika, dapat menggunakan di keseharian, sehingga siswa diharapkan bisa menerapkan matematika sebagai cara penalaran (berpikir kritis, sistematis, logis, dan objektif). Kemampuan berpikir kritis yaitu suatu kemampuan dimana keterampilan tersebut dapat dipelajaran dengan baik jika terdapat instruksi dan latihan (Peter, 2012). Hal demikian selaras dengan Su et al., (2016) yang memaparkan bahwa semua siswa memiliki kesempatan untuk meningkatkan kemampuan berpikir kritisnya ketika belajar matematika.

Berlandaskan pengamatan yang dilaksanakan di SMPN 2 Karawang Barat dari data yang diperoleh nilai rata-rata metematika kelas VII yakni 70, dari data tersebut didapat 20 siswa yang memiliki nilai masih dibawah KKM yang sudah diterapkan oleh sekolah. Sedangkan cakupan kemampuan yang perlu peserta didik miliki pada mata pelajaran matematika yaitu untuk membudayakan berpikir ilmiah secara kreatif, kritis, dan mandiri (Permendikbud No. 22 Tahun 2016, terkait standar isi). Dengan KKM yang masih rendah tersebut membuktikan bahwa keterampilan berpikir yang menjadi standar kompetensi lulusan pendidikan menengah belum dicapai secara maksimal. Nugroho \& Riyanto (2019) dalam penelitiannya menyebutkan bahwa siswa kelas VII SMP masih kesulitan mengembangkan daya pikir mereka dalam memahami matematika. Ketika di berikan tes awal untuk melihat kemampuan berpikir kritis, rata-rata siswa hanya mencapai 46,79. Hal ini tentu memberikan pengaruh pada kemampuan berpikir kritis siswa. Hal demikian selaras dengan hasil penelitian dari Widana, (2018) yang menyebutkan bahwa kemampuan berikir kritis siswa dalam pelajaran matematika masih rendah. Sedangkan Susanti \& Hartono (2019); Kane et al., (2016) menyebutkan bahwa kemampuan berpikir kritis siswa SMP termasuk sedang, serta guru perlu melakukan suatu cara agar meningkatkan kemampuan berpikir kritis siswa. sisBasri et al., (2019) menyebutkan bahwa kemampuan berpikir kritis siswa pada indikator evaluasi, analisis, keterampilan interpretasi dalam kategori sedang dan pengaturan diri masih termasuk rendah.

Menurut Paul dan Elder (2002); Cahyana et al., (2017) menyatakan bahwa, berpikir kritis yaitu proses tersistematis yang digunakan dalam hal pengambilan keputusan, pemecahan masalah, dan menganalisis sebuah pendapat. Seseorang yang berpikir lebih dari batas intelektualnya, akan semakin kritis cara berpikirnya, dalam proses pembelajar yang dilakukan, siswa mampu mengevaluasi pendapat pribadi dan pendapat orang lain secara sistematis. Menurut Facione (2015) Indikator yang digunakan dalam mengukur kemampuan berpikir kritis, yakni: (1) interpretasi ialah kemampuan dalam pemahaman atau memberikan sebuah informasi; (2) analisis yaitu menuliskan apa yang dilakukan dan menyelesaikan soal; (3) Evaluasi yaitu menggunakan cara yang tepat untuk menyelesaikan suatu perasalahan; dan (4) inferensi yaitu mengindentifikasi dan mendapatkan unsur yang diperlukan untuk mendapatkan suatu kesimpulan. Suatu rangkaian proses mengalisis dan berpikir untuk mengungkapkan pendapat menggunakan pemikiran yang logis merupakan berpikir kritis. Melalui berpikir kritis, siswa dapat fokus pada bagaimana membuat keputusan yang rasional, memikirkan apa yang harus dilakukan dengan keputusan terakhir, serta menjelaskan sesuatu yang menarik. 
Kane et al. (2016); Muhtadi et al., (2019) melakukan penelitian terakit kemampuan berpikir kritis jika ditinjau dari gaya kognitif siswa. Hasil penelitiannya menunjukkan bahwa ditemukan perbedaaan kemampuan berpikir kritis antara siswa dengan gaya kognitif field dependent dan field independent. Sementara Mawaddah et al., (2018) dalam penelitiannya meneliti tentang kemampuan berpikir kritis siswa berdasarkan gender, dan hasilnya membuktikan bahwa kemampuan berpikir siswa perempuan lebih baik daripada siswa laki-laki. Purwanto et al., (2020) melakukan penelitian kemampuan berpikir kritis berdasar dari gaya belajar, yang meberikan hasil bahwa gaya belajar tidak mempengaruhi kemampuan berpikir kritis, tetapi terdapat perbedaan kemampuan berpikir kritis pada masing-masing gaya belajar visual, auditorial, dan kinestetik. Berbeda dengan penelitian dari Setiawan et al., (2020) yang menunjukkan bahwa tidak ditemukan perbedaan kemampuan berpikir kritis pada siswa pada masing-masing kategori gaya belajar visual, auditori, dan kinestetik. Hal tersebut menjadi motivasi bagi penulis agar melihat lebih lanjut bagaimana kemampuan berpikir kritis siswa SMP Negeri 1 Karawang Barat jika dilihat dari gaya belajarnya. Kemampuan berpikir kritis memungkinkan siswa guna memproses pengetahuan ataupun informasi yang diperolehnya secara logis serta mendorong siswa untuk belajar secara mandiri (Su et al., 2016; Umar, 2017)).

Kemampuan berpikir kritis dapat dikembangkan melalui identifikasi gaya belajar siswa (Purwanto et al., 2020). Gaya belajar mempengaruhi proses belajar maka dari itu perlu untuk mengidentifikasi kecenderungan gaya belajar siswa agar dapat bermanfaat dalam pengembangan proses belajar mengajar (Mar'ah, 2015; Hamidon, 2015; Özerem \& Akkoyunlu, 2015). Oleh sebab itu, dalam situasi covid seperti ini sangat diperlukan untuk mengetahui bagaimana gaya belajar siswa, agar bisa mengetahui pembelajaran seperti apa yang dapat dipergunakan oleh pengajar sebagai alternatif model pembelajaran pada pembelajaran jarak jauh. Cara siswa dalam menangkap dan memahami informasi yang berbeda adalah salah satu yang memberi pengaruh pada proses belajar. Perasaan nyaman, cara memahami, dan perilaku yang dimiliki oleh setiap siswa ketika belajar disebut dengan gaya belajar (Mayaningtyas, 2016). Karna setiap siswa pasti memiliki cara belajar dan waktu belajar sesuai keinginan dan sesuai kenyamannya sendiri. Gaya belajar merupakan cara seorang individu agar memahami dan mempelajari informasi baru yang didapat dari sekelilingnya (DePorter \& Hernacki, 2011). Tiap siswa mempunyai cara dalam mempelajari ataupun memahami sesuatu yang berbeda-beda sesuai kenyamannya sendiri. Gaya belajar merupakan keadaan dimana seseorang dapat memahami, memproses informasi dan mengerti yang telah didapat sebelumnya dalam pembelajaran (Brown, 2000; Kurniati \& Sari, 2019). Gaya belajar adalah cara individu untuk menerima informasi mempergunakan tingkat kefokusan yang berbeda supaya bisa mendapatkan hasil optimal (Fadhilah, 2018; Rahmayani, 2017). Langkah awal dalam pengalaman belajar adalah mengenal gaya belajar, seorang siswa harus memahami gaya belajar mereka sendiri serta bisa memilih cara belajar berdasarkan karakter dirinya. Gaya belajar merupakan kemampuan seseorang untuk memahami, kemudian mengolah informasi unmentuk tercapainya prestasi belajar ataupun memaksimalkan kualitas pendidikan (Maula, 2017). Seseorang memiliki 3 jenis gaya belajar yakni gaya belajar auditorial, visual, serta kinestetik yang 
disebut dengan gaya belajar tipe V-A-K (DePorter \& Hernacki, 2011). Indikator gaya belajar yang dipakai pada penelitian ini, (1) gaya belajar visual yaitu, rapih dan teratur, orientasi melihat, cara membaca, cara berbicara, lingkungan; (2) gaya auditorial yaitu, orientasi mendengar, cara membaca, cara berbicara, lingkungan; (3) gaya belajar kinestetik yaiu, orientasi gerak, cara membaca, cara berbicara, dan lebih suka praktik atau percobaan. Maka bisa disimpulkan gaya belajar adalah cara belajar yang digunakan siswa untuk berinteraksi, serta mendapatkan informasi dengan mudah dan nyaman.

Hasil penelitian dari Singh et al., (2018) menjelaskan bahwa gaya belajar siswa sekolah menengah didominasi oleh gaya belajar visual $(45,7 \%)$, selanjutnya auditori sebesar $(21 \%)$ dan sisanya memiliki gaya belajar taktil dan kinestetik. Selajan dengan Ishartono et al., (2021); Jamulia (2018) dalam penelitiannya menyebutkan bahwa beberapa siswa memiliki gaya belajar visual. Hasil penelitian dari Permana (2020) menyebutkan bahwa gaya belajar visual paling memberi pengaruh signitfikan pada kemampuan penyelesaian masalah siswa. Apipah et al., (2018) juga menyebutkan bahwa siswa dengan gaya belajar visual mempunyai kemampuan koneksi matematis yang lebih baik jika di banding dengan siswa yang mempunyai gaya belajar kinestetik dan auditori. Indraswari et al., (2018) dalam penelitiannya menyebutkan bahwa siswa dengan gaya belajar kinestetik dan visual menuliskan penyelesaikan masalah matematika menggunakan symbol/kalimat matematika secara umum, sementara siswa yang bergaya belajar auditori menuliskan penyelesaian dalam bentuk kalimat. Setiana \& Purwoko (2020) menganalisis kemampuan berpikir kritis berdasarkan dari gaya belajar yang memberikan hasil kemampuan berpikir kritis siswa bergaya belajar kinestetik dalam kategori baik, kemampuan berpikir kritis siswa bergaya belajar visual dalam kategori sangat baik, dan kemampuan berpikir kritis siswa bergaya belajar auditorial dengan kategori cukup. Berbanding terbaik dengan hasil penelitian dari Amir (2015) yang menyebutkan bahwa siswa yang bergaya belajar kinestetik mempunyai proses berpikir kritis yang lebih baik daripada siswa yang bergaya belajar auditori dan visual.

Berdasarkan beberapa argumen ahli dan hasil penelitian tersebut peneliti merasa perlu untuk melakukan penelitian terkait kemampuan berpikir kritis dan gaya belajar mengingat pentingnya kedua aspek tersebut dalam proses belajar mengajar kedepannya, karena dari tiap kategori gaya belajar mempunyai kategori kemampuan yang berbeda dalam menyelesaikan masalah matematika, sehingga potensi yang dimiliki dapat dikembangkan dalam kemampuan berpikir kritis matematis. Penelitian akan berfokus pada analisis kemampuan berpikir kritis matematis siswa yang ditinjau dari gaya belajar dalam menyelesaikan masalah matematika pada materi operasi hitung bentuk aljabar pada siswa SMP kelas VII.

\section{METODE}

Jenis penelitian yang dipergunakan yaitu penelitian deskriptif kualitatif. Metode ini dipilih oleh peneliti yang tujuannya guna menggambarkan kemampuan berpikir kritis matematis pada pembelajaran matematika SMP pada materi operasi hitung aljabar dilihat dari gaya belajar. Peneliti memilih 40 siswa kelas VII A sebagai calon subjek penelitian. Penelitian dilaksanakan di SMPN 1 Karawang Barat via 
online dengan menggunakan zoom karena pada saat penelitian dilakukan sedang dalam kondisi pandemic Covid-19. Subjek penelitian ini merupakan 9 siswa kelas VII A yang memiliki gaya belajar auditorial, visual, dan kinestetik, pada tiap kategori gaya belajar dipilih 3 siswa. Pemilihan subjek menerapkan metode purposive sampling, pengambilan subjek berdasarkan rekomendasi dari guru karena dilihat dari nilai dan keaktifan dalam proses pembelajaran.

Penggumpulan data dilakukan dengan menggunakan instrument angket gaya belajar, selanjutnya dilaksanakan wawancara dan uji kemampuan berpikir kritis matematis. Instrumen kemampuan berpikir kritis matematis yang digunakan yaitu tes essay/uraian sebanyak 5 soal dengan waktu 90 menit. Tes ini bertujuan untuk mengukur kemampuan berpikir kritis matematis subjek penelitian. Soal yang diberikan berdasarkan indikator kemampuan berpikir kritis matematis atau sudah diuji validitas oleh validasi ahli dan validitas konstruk serta reliabilitasnya. Indikator yang dipergunakan untuk menilai kemampuan berpikir kritis matematis pada penelitian ini, yaitu: (1) interpretasi yaitu kemampuan untuk memahami dan memberikan sebuah informasi; (2) analisis yaitu bisa menulis apa yang harus dilakukan dan menjawab soal; (3) Penilaian yaitu menerapkan strategi yang tepat untuk memecahkan suatu perasalahan; serta (4) inferensi yaitu mengindentifikasi dan mendapatkan unsur yang diperlukan untuk mendapatkan suatu kesimpulan.

Dalam mengelompokkan siswa berdasarkan gaya belajarnya menggunakan kuesioner gaya belajar. Siswa diberikan angket yang meliputi 36 item pertanyaan berdasarkan kisi-kisi yang sudah disusun yaitu 12 butir pertanyaan auditorial, 12 butir pertanyaan visual, dan 12 butir pertanyaan kinestetik. Penyusunan instrument angket menggunakan skala Likert dengan 5 pilihan jawaban, yakni tidak setuju, ragu-ragu, sangat tidak setuju, setuju, sangat setuju. Setiap pilihan jawaban memiliki skor 1-5. Hasil angket ini untuk menentukan kategori gaya belajar pada setiap siswa. Selanjutnya, skor angket akan dijumlahkan untuk setiap kategori gaya belajar. Skor paling tinggi diantara ketiga jenis gaya belajar tersebut memperlihatkan jenis gaya belajar yang dimiliki oleh siswa. Selanjutnya dari 40 siswa dipilih 3 siswa dari setiap kategori tipe gaya belajar.

Metode wawancara ini digunakan untuk mewawancarai siswa yang telah terpilih menjadi subjek penelitian, dan bertujuan untuk mendapatkan informasi pendukung. Peneliti melakukan wawancara dengan peserta didik dengan menggunakan voice note. Dokumentasi juga digunakan sebagai alat bantu untuk menggumpulkan data berupa foto untuk jawaban hasil peserta didik.

Teknik analisa data pada penelitian ini menerapkan analisa data model Miles dan Huberman, kegiatan dalam analisa data ini yakni penyajian data (data display), reduksi data (data reduction), serta penarikan kesimpulan/verifikasi (conclusion drawing/verification) (Sugiyono, 2017). Triangulasi pada penelitian ini yaitu triangulasi waktu. Data tersebut digunakan untuk mengetahui kemampuan berpikir kritis yang digunakan oleh masing-masing subjek penelitian gaya belajar dengan tipe auditorial, visual, ataupun kinestetik. 


\section{HASIL DAN DISKUSI}

\section{Hasil}

Angket gaya belajar diujikan pada 40 siswa, selanjutnya digunakan untuk mengkategorikan siswa dengan gaya belajar auditorial, visual, serta kinestetik. Hasil analisis gaya belajar siswa dapat dilihat pada Tabel 1.

Tabel 1. Data kategori gaya belajar

\begin{tabular}{|c|c|c|}
\hline Gaya belajar & Banyak siswa & Subjek penelitian \\
\hline \multirow{3}{*}{ Visual } & \multirow{3}{*}{22} & V1 (Visual 1) \\
\hline & & V2 (Visual 2) \\
\hline & & V3 (Visual 3) \\
\hline \multirow{3}{*}{ Auditorial } & \multirow{3}{*}{10} & A1 (Auditorial 1) \\
\hline & & A2 (Auditorial 2) \\
\hline & & A3 (Auditorial 3) \\
\hline \multirow{3}{*}{ Kinestetik } & \multirow{3}{*}{8} & K1 (Kinestetik 1) \\
\hline & & K2 (Kinestetik 2) \\
\hline & & K3 (Kinestetik 3) \\
\hline
\end{tabular}

Berdasarkan Tabel 1 diatas diperoleh hasil analisis dari skor angket gaya belajar yang diberikan. Sejalan dengan Singh et al., (2018) menjelaskan bahwa gaya belajar siswa sekolah menengah didominasi oleh gaya belajar visual $(45,7 \%)$, selanjutnya auditori sebesar $(21 \%)$ dan sisanya memiliki gaya belajar taktil dan kinestetik. Sejalan dengan Ishartono et al., (2021); Jamulia (2018)) dalam penelitiannya memaparkan bahwa sebagian besar siswa mempunyai gaya belajar visual. Pengelompokkan tiap gaya belajar siswa berdasarkan pada kecenderungan nilai siswa pada kategori gaya belajar yang sesuai. Skor maksimum yang dimiliki siswa pada kategori gaya tertentu menunjukkan bahwa siswa memiliki kecenderungan pada kategori gaya belajar tertentu. Berdasar hasil analisis angket gaya belajar, terdapat 10 siswa bergaya belajar auditorial, 22 siswa bergaya belajar visual, 8 siswa bergaya belajar kinestetik. Kemudian hasil pengelompokkan tersebut dipilih 3 siswa untuk setiap kategori siswa bergaya belajar visual, auditorial, serta kinestetik. Subjek bergaya belajar visual yang terpilih adalah siswa yang bernama AN, AUF, RHH. Subjek bergaya belajar auditorial yang terpilih ialah siswa yang bernama SN, GRR, GA. Subjek bergaya belajar kinestetik yang terpilih adalah siswa yang bernama SSR, AA, BLD.

Sebelum hasil pengisian angket, dalam penelitian ini diperoleh data hasil TKBKM (Tes Kemampuan Berpikir Kritis Matematis) dan transkip wawancara. Data wawancara tiap subjek dijelaskan dan diuraikan untuk bisa melihat kemampuan beprikir kritis matematis siswa. Berikut disajikan hasil tes tertulis dan transkip wawancara pada TKBKM 2 dan TKBKM 1 untuk subjek bergaya belajar visual, auditorial, dan kinestetik.

\section{Subjek 1 AN Bergaya belajar visual (V1)}

Pertanyaan nomor 1 pada TKBKM 1 yaitu: "Selisih uang Adik dan kakak Rp 20.000, dua kali uang kakak ditambah uang adik dengan jumlah Rp 50.000. Tentukan Total uang mereka!”. Pertanyaan 
soal nomor 1 pada TKBKM 1 dan TKBKM 2 adalah soal yang sama namun dibedakan angka pada selisih uang adik dan kakak.

Subjek V1 berinisial AN dalam menjawab soal nomer 1 pada TKBKM 1 kurang teliti, tetapi dalam menuliskan jawaban secara rinci. Subjek V1 dapat menuliskan informasi yang diperoleh dari pertanyaan nomer 1 pada TKBKM 1 secara lengkap. Pada langkah analisis, subjek V1 menggunakan rumus sesuai yang ditanyakan, tetapi ada kekeliruan dalam menjawab hasil yang diperoleh pada lembar jawaban subjek V1 seharusnya $\mathrm{y}=10.000$, tetapi subjek V1 menuliskannya $\mathrm{y}=20.000$. Pada langkah penilaian, subjek V1 menerapkan cara yang tepat untuk menjawab perhitungan atau penjelasan soal nomor 1 di TKBKM 2 dan TKBKM 1. Pada langkah kesimpulan, subjek A1 mampu menjelaskan kesimpulan secara tepat, berdasar konteks soal dan lengkap. Subjek V1 sudah mampu dalam memenuhi langkah-langkah dalam menyelesikan soal pada TBKM 2 karena penyelesaian yang dikerjakan sesuai dengan indikator kemampuan berpikir kritis. Subjek V1 sudah mampu dalam berpikir kritis, tetapi dalam proses pengerjaan yang dilakukan kurang teliti, karena masih terdapat kesalahan dalam penulisan hasil pada jawaban. Dalam hal ini, subjek V2 dan V3 mampu dalam memenuhi langkah-langkah untuk menyelesikan soal, karena penyelesaian yang dikerjakan dapat sesuai dengan indikator kemampuan berpikir kritis.

Hasil jawaban subjek V1 disajikan Gambar 1 dan hasil wawancara pertanyaan soal nomor 1 dilihat pada tabel 2

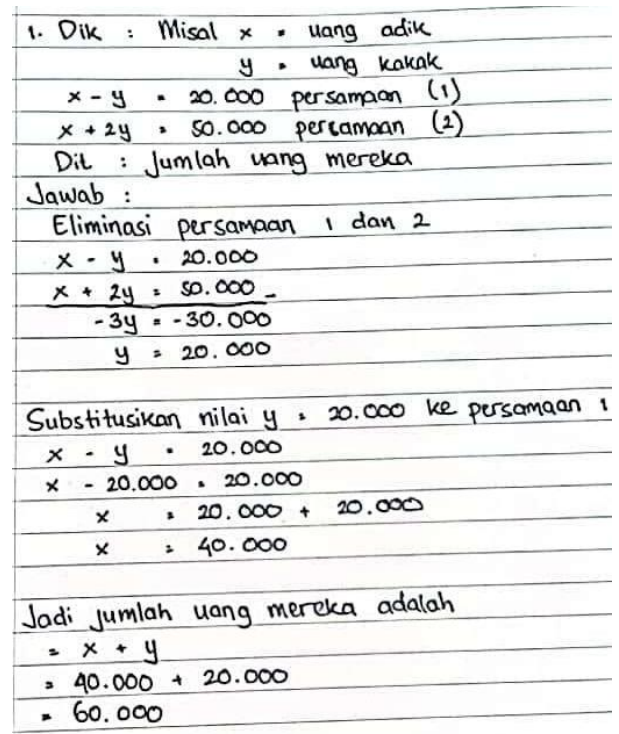

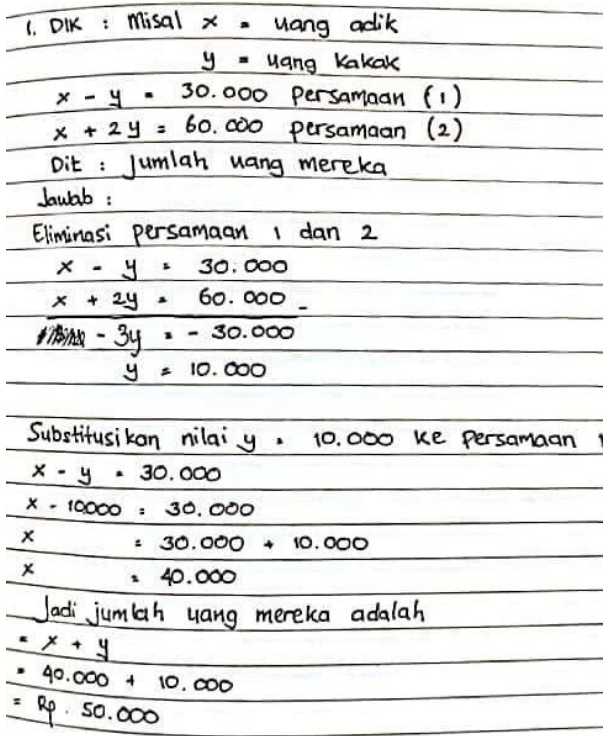

Gambar 1. Jawaban Tes Tertulis Subjek AN pada TKBKM 1 (kiri) dan TKBKM 2 (kanan)

Dari Gambar 1 menunjukkan bahwa jawaban tertulis subjek V1 pada TKBKM 1 dan TKBKM 2 konsisten pada TKBKM 2 subjek V1 bisa menjawab secara tepat dan benar dan menggunakan cara yang sama dengan sebelumnya, dengan demikian bisa dianggap bahwa pertanyaan untuk nomor 1 tersebut valid. 
Tabel 2. Transkip Wawancara Subjek V1

\begin{tabular}{|l|l|l|l|}
\hline & \multicolumn{1}{|c|}{ TKBKM 1 } & & \multicolumn{1}{|c|}{ TKBKM 2 } \\
\hline $\mathrm{P}$ & $\begin{array}{l}\text { Di soal nomor 1, apakah kamu paham dan } \\
\text { mengerti dengan pertanyaan dari soal? }\end{array}$ & $\mathrm{P}$ & $\begin{array}{l}\text { Di soal nomor 1, apakah kamu paham dan } \\
\text { mengerti dengan pertanyaan dari soal? }\end{array}$ \\
\hline V1 & Iya, saya paham bu & V1 & $\begin{array}{l}\text { Iya, saya paham bu karena cara nya sama } \\
\text { kaya kemarin }\end{array}$ \\
\hline P1 & $\begin{array}{l}\text { Informasi apa yang kamu dapatkan dari } \\
\text { pertanyaan yang ada pada soal? }\end{array}$ & $\begin{array}{l}\text { Karena yang diketahui selisih uang adik } \\
\text { dan kakak, terus dimisalkan uang adik } \\
\text { dan uang kakak = y, setelah itu saya cari } \\
\text { jumlah uang mereka dengan cara eliminasi } \\
\text { terus masukin persamaan 1 dan 2, terus } \\
\text { ketemu nilai awal y untuk hasil uang } \\
\text { kakak. Tapi saya salah nulis bu untuk } \\
\text { hasilnya, seharusnya 10.000 saya kurang } \\
\text { teliti. }\end{array}$ & V1 \\
\hline P & $\begin{array}{l}\text { Baik tidak apa-apa, lalu setelah itu } \\
\text { pertanyaan yang ada pada soal? }\end{array}$ & $\begin{array}{l}\text { Bedanya hanya angkanya saja bu, soal yg } \\
\text { ini saya tulis lagi sama kaya jawaban yang } \\
\text { sebelumnya. } \\
\text { menyelesaikan soal tersebut? }\end{array}$ \\
\hline V1 & $\begin{array}{l}\text { Saya pake cara eliminasi dan dapet nilai y } \\
\text { nya, saya pake cara substitusi buat dapetin } \\
\text { nilai x atau uang kakak }\end{array}$ & V1 & $\begin{array}{l}\text { Yakin bu, karena saya periksa kembali } \\
\text { hasil jawaban saya, tapi saya gatau bener } \\
\text { apa tidak }\end{array}$ \\
\hline $\mathrm{P}$ & $\begin{array}{l}\text { Setelah nilai x dan y nya didapat apa } \\
\text { langkah selanjutnya? }\end{array}$ & $\begin{array}{l}\text { Apakah kamu yakin dengan hasil jawaban } \\
\text { yang kamu berikan ini? }\end{array}$ \\
\hline V1 & $\begin{array}{l}\text { Nilai x dan y nya didapat, } \\
\text { dikesimpulannya saya tambahin bu x + y, } \\
\text { setelah itu dapet hasilnya }\end{array}$ & & \\
\hline
\end{tabular}

Hasil wawancara pada tabel 2 menunjukkan bahwa subjek V1 dapat menjelaskan jawaban yang ditulis secara baik, karena pada TKBKM 1 subjek memberitahu jika salah dalam perhitungan hasil.

\section{Subjek 2 SN Bergaya belajar Auditorial (A1)}

Pertanyaan soal nomor 1 pada TKBKM 2 dan TKBKM 1 merupakan pertanyaan yang sama yang membedakan hanya angkanya pada selisih uang adik dan kakak. Subjek A1 berinisial SN dalam menjawab soal nomer 1 pada TKBKM 1 sangat teliti dan menuliskan jawaban dengan secara rinci. Subjek A1 menuliskan apa yang ditanyakan ataupun dipahami pada soal dengan tepat, namun masih kurang lengkap yang diperoleh dari pertanyaan nomer 1 pada TKBKM 1 dan TKBKM 2 karena hanya menuliskan permisalan "A-K $=$ Rp. 20.000 dan $2 \mathrm{~K}+\mathrm{A}=$ Rp. 50.000" tidak diberikan keterangan variabel A sebagai siapa, dan variabel $\mathrm{K}$ sebagai siapa, maka seharusnya ditambahkan " $\mathrm{A}$ = Adik, $\mathrm{K}=$ Kakak". Namun pada langkah analisis, subjek A1 membuat model matematika menggunakan rumus eliminasi dan substitusi secara tepat serta menjelaskan dengan lengkap ataupun benar. Pada langkah evaluasi, subjek A1 menerapkan cara yang tepat untuk menjawab perhitungan atau penjelasan soal nomor 1 di TKBKM 2 dan TKBKM 1. Pada langkah kesimpulan, subjek A1 mampu menjelaskan kesimpulan secara tepat, berdasar konteks soal dan lengkap. Subjek A1, A2, dan A3 mampu dalam menyelesikan soal karena penyelesaian yang dikerjakan sesuai dengan indikator kemampuan berpikir 
kritis yakni, analisis, evaluasi, interpretasi, serta inferensi. Subjek A1 sudah mampu dalam berpikir kritis. Berikut data jawaban subjek A1 disajikan pada Gambar 2 dan hasil wawancara pertanyaan nomor 1 disajikan pada tabel 3 .
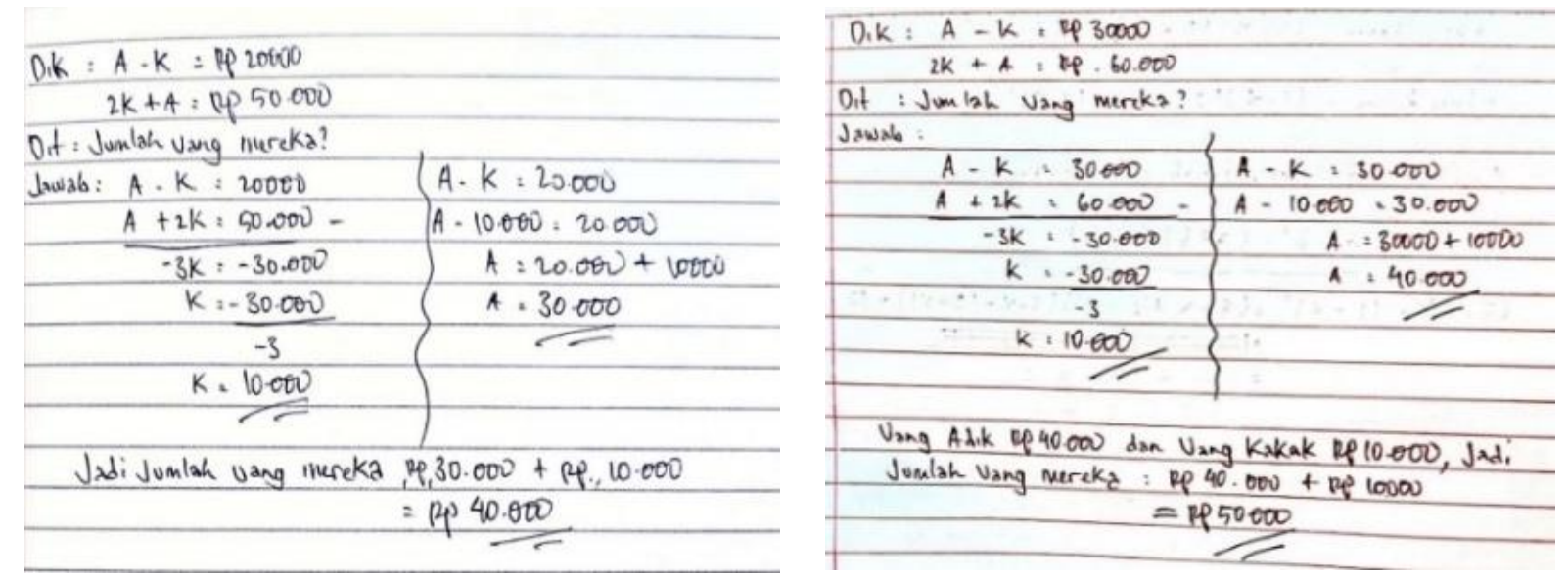

Gambar 2. Tes tertulis subjek A1 pada TKBKM 1 (kiri) dan TKBKM 2 (kanan)

Tabel 3. Hasil wawancara subjek A1

\begin{tabular}{|c|c|c|c|}
\hline & TKBKM 1 & & TKBKM 2 \\
\hline $\mathrm{P}$ & $\begin{array}{l}\text { Di soal nomor 1, apakah kamu paham dan } \\
\text { mengerti dengan pertanyaan dari soal? }\end{array}$ & $\mathrm{P}$ & $\begin{array}{l}\text { Di soal nomor 1, apakah kamu paham dan } \\
\text { mengerti dengan pertanyaan dari soal? }\end{array}$ \\
\hline A1 & $\begin{array}{l}\text { Untuk soal ini saya paham dan mengerti, } \\
\text { karena materi itu belum lama saya pelajari } \\
\text { untuk ujian sekolah bulan lalu }\end{array}$ & A1 & $\begin{array}{l}\text { Iya saya paham soal itu, karena soal itu } \\
\text { juga sama seperti soal sebelumnya }\end{array}$ \\
\hline $\mathrm{P}$ & $\begin{array}{l}\text { Informasi apa yang kamu dapatkan dari } \\
\text { pertanyaan yang ada pada soal? }\end{array}$ & $\mathrm{P}$ & $\begin{array}{l}\text { Informasi apa yang kamu dapatkan dari } \\
\text { pertanyaan yang ada pada soal? }\end{array}$ \\
\hline A1 & $\begin{array}{l}\text { Disuruh mencari selisih uang adik dan } \\
\text { kakak dan ditanya berapa jumlah mereka, } \\
\text { selain itu dari soal tersebut saya bisa } \\
\text { menghitung perbandingan seperti untuk } \\
\text { kegiatan sehari-hari yang lainnya }\end{array}$ & A1 & $\begin{array}{l}\text { Sama seperti soal yang sebelumnya yang } \\
\text { hanya membedakan angkanya saja, saya } \\
\text { memakai cara dan rumus yang sama } \\
\text { seperti soal sebelumnya }\end{array}$ \\
\hline $\mathrm{P}$ & $\begin{array}{l}\text { Bagaimana selanjutnya cara kamu } \\
\text { menyelesaikan soal tersebut? }\end{array}$ & $\mathrm{P}$ & $\begin{array}{l}\text { Apakah kamu yakin dengan hasil jawaban } \\
\text { yang kamu berikan ini? }\end{array}$ \\
\hline A1 & $\begin{array}{l}\text { Rumusnya saya mengambil dari materi } \\
\text { aljabar, dan saya substitusikan angka- } \\
\text { angkanya sehingga saya dapat jawaban } \\
\text { untuk soal tersebut }\end{array}$ & A1 & Iya, saya yakin \\
\hline $\mathrm{P}$ & $\begin{array}{l}\text { Menurut kamu, apakah ada rumus lain } \\
\text { yang bisa dipergunakan dalam menjawab } \\
\text { soal tersebut? }\end{array}$ & & \\
\hline A1 & $\begin{array}{l}\text { Untuk saat ini saya tidak tahu, karena } \\
\text { sampai sekarang saya hanya } \\
\text { menggunakan cara itu untuk mengerjakan } \\
\text { soal-soal seperti nomer } 1\end{array}$ & & \\
\hline
\end{tabular}

Hasil dari wawancara pada tabel 3, menunjukkan bahwa subjek A1 bisa menerangkan tiap tahap pada jawaban yang ditulis secara baik atas jawaban yang sudah ia kerjakan. 


\section{Subjek 3 GRR Bergaya belajar Kinestetik (K1)}

Pertanyaan soal nomor 1 pada TKBKM 2 dan TKBKM 1 merupakan pertanyaan yang sama yang membedakan hanya angkanya saja pada selisih uang adik dan kakak. Subjek K1 berinisial GRR dalam menjawab soal nomer 1 pada TKBKM 1 kurang teliti dan tidak menuliskan jawaban dengan tepat. Pada langkah interpretasi, subjek K1 kurang pada penulisan informasi apa yang ditanyakan ataupun dipahami yang diperoleh dari pertanyaan nomer 1 pada TKBKM 1 dan TKBKM 2 secara lengkap karena subjek 1 hanya menuliskan "adik $=\mathrm{x}$ dan kakak $=\mathrm{y}$ ". Pada langkah analisis, subjek K1 tidak tepat dalam membuat model matematika menggunakan rumus eliminasi dan substitusi dengan pertanyaan yang ada pada soal. Pada langkah penilaian, subjek K1 menerapkan strategi yang kurang tepat untuk mengerjakan perhitungan atau penjelasan pada soal nomor 1 pada TKBKM 1 dan TKBKM 2. Pada langkah inferensi, subjek K1 mampu menjelaskan kesimpulan tetapi kurang tepat dalam hasil. Subjek K1 kurang mampu dalam berpikir kritis. Sedangkan subjek K2 dan K3 mampu dalam memenuhi langkah-langkah dalam menyelesikan soal sesuai dengan indikator kemampuan berpikir kritis yakni analisis, evaluasi, interpretasi, serta inferensi. Subjek K2 dan K3 mampu dalam berpikir kritis. Jawaban subjek K1 disajikan pada Gambar 3 dan hasil wawancara pertanyaan soal nomor 1 disajikan pada tabel 4.
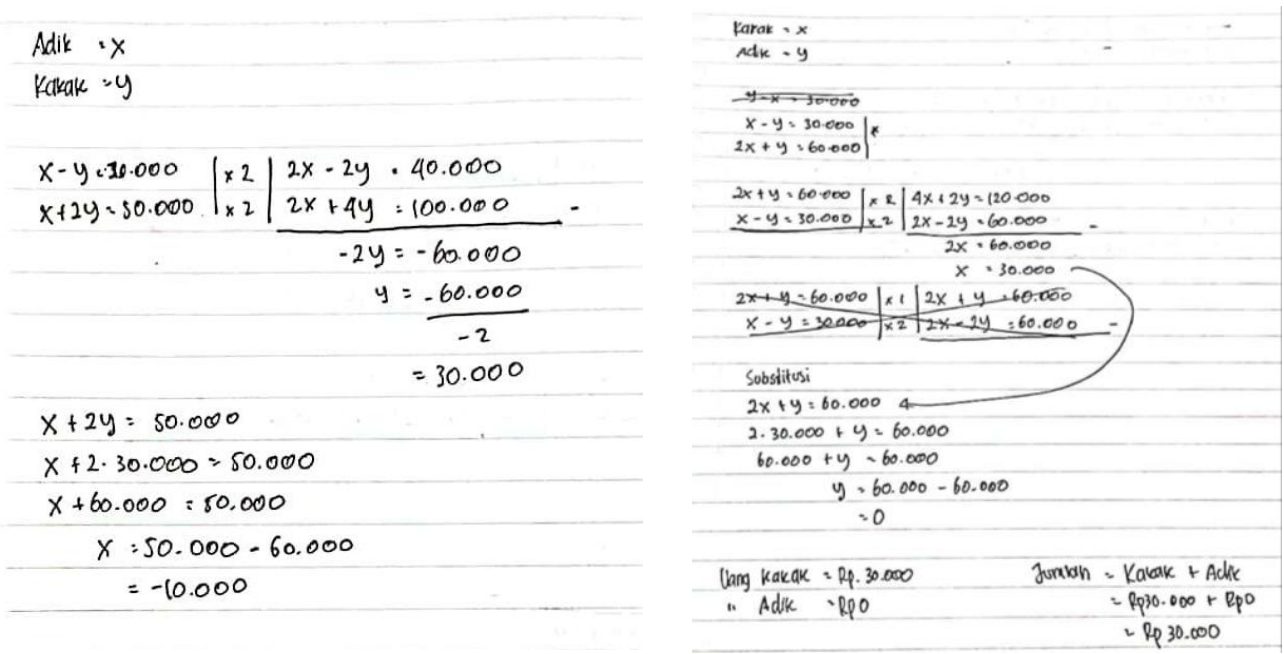

Gambar 5. Tes tertulis subjek K1 pada TKBKM 1 (kiri) dan TKBKM 2 (kanan)

Tabel 4. Hasil wawancara subjek K1

\begin{tabular}{|l|l|l|l|}
\hline & \multicolumn{1}{|c|}{ TKBKM 1 } & & \multicolumn{1}{c|}{ TKBKM 2 } \\
\hline $\mathrm{P}$ & $\begin{array}{l}\text { Di soal nomor 1, apakah kamu paham dan } \\
\text { mengerti dengan pertanyaan dari soal? }\end{array}$ & $\mathrm{P}$ & $\begin{array}{l}\text { Di soal nomor 1, apakah kamu paham dan } \\
\text { mengerti dengan pertanyaan dari soal? }\end{array}$ \\
\hline $\mathrm{K} 1$ & saya paham dengan pertanyaannya & $\mathrm{K} 1$ & $\begin{array}{l}\text { Iya paham bu, karena hanya beda di angka } \\
\text { saja }\end{array}$ \\
\hline $\mathrm{P}$ & $\begin{array}{l}\text { Informasi apa yang kamu dapatkan dari } \\
\text { pertanyaan yang ada pada soal? }\end{array}$ & $\mathrm{P}$ & $\begin{array}{l}\text { Informasi apa yang kamu dapatkan dari } \\
\text { pertanyaan yang ada pada soal? }\end{array}$ \\
\hline $\mathrm{K} 1$ & $\begin{array}{l}\text { Saya memakai cara cepat dan mudah } \\
\text { menyelesaikan soal cerita dengan metode } \\
\text { aljabar }\end{array}$ & $\mathrm{K} 1$ & $\begin{array}{l}\text { Sama seperti soal yang kemaren diberikan } \\
\text { hanya saja saya bingung kenapa dari cara } \\
\text { yang saya pakai adiknya gak punya yang }\end{array}$ \\
\hline
\end{tabular}




\begin{tabular}{|l|l|l|l|}
\hline & & & $\begin{array}{l}\text { mulu jadi saya gatau ini jawaban saya } \\
\text { yang eror atau gimana }\end{array}$ \\
\hline $\mathrm{P}$ & $\begin{array}{l}\text { Selanjutnya, bagaimanacara kamu } \\
\text { menyelesaikan soal tersebut? }\end{array}$ & $\mathrm{P}$ & $\begin{array}{l}\text { Apakah kamu yakin dengan hasil jawaban } \\
\text { yang kamu berikan ini? }\end{array}$ \\
\hline $\mathrm{K} 1$ & $\begin{array}{l}\text { Dengan menggunakan metode yang } \\
\text { terdapat dalam aljabar, substitusi dan } \\
\text { eliminasi }\end{array}$ & $\mathrm{K} 1$ & $\begin{array}{l}\text { Tidak sepenuhnya yakin, tapi dengan } \\
\text { rumus yang saya terapkan semoga } \\
\text { jawaban saya bisa benar }\end{array}$ \\
\hline
\end{tabular}

Hasil dari wawancara pada tabel 3, diketahui bahwa subjek A1 kurang dalam menerangkan setiap langkah pada jawaban yang dituliskannya.

\section{Diskusi}

Hasil penelitian ini yaitu hasil subjek V1 dan A1 yang memiliki kemampuan berpikir kritis matematis dan mampu menjawab uji kemampuan berpikir kritis matematis yang ada pada yakni, analisis, evaluasi, interpretasi, serta inferensi pada setiap pertanyaan yang diberikan dan dikerjakan. Sedangkan untuk subjek K1, kurang baik saat menjawab uji kemampuan berpikir kritis matematis, hal tersebut ditunjukkan dengan kurang telitinya subjek K1 ketika menuliskan jawaban dari pertanyaan pada soal, kurang mampu mencapai indikator berpikir kritis matematis. Berikut diberikan tabel 5 mengenai deskripsi kemampuan berpikir kritis matematis dilihat dari gaya belajar.

Tabel 5. Dekskripsi kemampuan berpikir kritis matematis ditinjau dari gaya belajar

\begin{tabular}{|c|c|c|}
\hline Subjek Visual (V1, V2, V3) & $\begin{array}{l}\text { Subjek Auditorial (A1, A2, } \\
\text { A3) }\end{array}$ & $\begin{array}{c}\text { Subjek Kinestetik (K1, K2, } \\
\text { K3) }\end{array}$ \\
\hline \multicolumn{3}{|c|}{ Pertanyaan nomor 1} \\
\hline $\begin{array}{l}\text { Pada soal TKBKM 1 dan } 2 \\
\text { subjek V1, V2, dan V3, mampu } \\
\text { memenuhi indikator } \\
\text { kemampuan berpikir kritis } \\
\text { yakni analisis, evaluasi, } \\
\text { interpretasi, serta inferensi. } \\
\text { Karena pada langkah } \\
\text { interpretasi siswa dapat } \\
\text { menuliskan apa yang dipahami } \\
\text { ataupun ditanya. Pada langkah } \\
\text { analisis, subjek mampu } \\
\text { menjelaskan dengan baik } \\
\text { menggunakan rumus eliminasi } \\
\text { dan substitusi, akan tetapi ada } \\
\text { kekeliruan dalam menjawab } \\
\text { hasil, pada subjek V1 } \\
\text { seharusnya } y=\mathbf{1 0 . 0 0 0 ,} \\
\text { tetapi subjek V1 } \\
\text { menuliskannya } \boldsymbol{y}=\mathbf{2 0 . 0 0 0 .} \\
\text { Pada langkah evaluasi, strategi } \\
\text { yang digunakan tepat dalam } \\
\text { perhitungan atau penjelasan. } \\
\text { Pada langkah kesimpulan, } \\
\text { subjek mampu menjelaskan }\end{array}$ & $\begin{array}{l}\text { Pada pernyataan soal nomor } 1 \\
\text { subjek A1, A2, dan A3, sudah } \\
\text { mampu memenuhi indikator } \\
\text { yakni interpretasi, analisis, } \\
\text { evaluasi, serta inferensi. Tetapi } \\
\text { pada langkah interpretasi subjek } \\
\text { A1 kurang lengkap menuliskan } \\
\text { yang diperoleh pada soal } \\
\text { TKBKM } 1 \text { dan } 2 \text { karena hanya } \\
\text { menuliskan permisalan "A-K = } \\
\text { Rp. 20.000 dan } 2 \mathrm{~K}+\mathrm{A}=\mathrm{Rp} . \\
\text { 50.000" tetapi tidak diberikan } \\
\text { keterangan variabel A sebagai } \\
\text { siapa, dan variabel K sebagai } \\
\text { siapa, maka seharusnya } \\
\text { ditambahkan "A = Adik, K= } \\
\text { Kakak". Pada langkah analisis, } \\
\text { subjek menggunakan rumus } \\
\text { eliminasi dan substitusi. Pada } \\
\text { langkah evaluasi, strategi yang } \\
\text { digunakan subjek tepat dalam } \\
\text { perhitungan dan penjelasan. } \\
\text { Pada langkah kesimpulan, subjek } \\
\text { mampu menjelaskan sesuai } \\
\text { konteks soal. }\end{array}$ & $\begin{array}{l}\text { Untuk soal nomor 1 pada } \\
\text { TKBKM 1 dan } 2 \text { subjek K2 dan } \\
\text { K3 telah memenuhi indikator } \\
\text { yakni analisis, evaluasi, } \\
\text { interpretasi, serta inferensi. } \\
\text { Tetapi dalam interpretasi, subjek } \\
\text { K1 kurang dalam menuliskan } \\
\text { informasi apa yang ditanyakan } \\
\text { ataupun dipahami dari } \\
\text { pertanyaan nomer } 1 \text { pada soal } \\
\text { TKBKM 1 dan } 2 \text { secara lengkap } \\
\text { karena subjek K1 hanya } \\
\text { menuliskan "adik } x \text { dan kakak } \\
=\text { y". Pada langkah analisis, } \\
\text { subjek K1 kurang tepat dalam } \\
\text { menyusun model matematika } \\
\text { yang menggunakan rumus } \\
\text { eliminasi dan substitusi. Pada } \\
\text { langkah penilaian, subjek K1 } \\
\text { mempergunakan strategi yang } \\
\text { tidak sesuai dalam } \\
\text { menyelesaikan perhitungan atau } \\
\text { penjelasan. Pada langkah } \\
\text { kesimpulan, subjek K1 mampu }\end{array}$ \\
\hline
\end{tabular}


Pada soal nomor 3 untuk TKBKM 1 dan 2 ini subjek V1, $\mathrm{V} 2$, dan V3, mampu memenuhi indikator yang diberikan yakni analisis, evaluasi, interpretasi, dan inferensi. Karena pada langkah interpetasi, subjek mampu menuliskan apa yang dipahami ataupun tanyakan. Menggunakan rumus luas persegi dan pemfaktoran aljabar bentuk selisih kuadrat berdasar pertanyaan yang ada pada soal dengan tepat, pada langkah analisis. Pada langkah evaluasi, subjek menerapkan strategi yang sesuai pada perhitungan atau penjelasan. Pada langkah kesimpulan, subjek mampu menjelaskan serta menjabarkan kesimpulan dengan tepat.

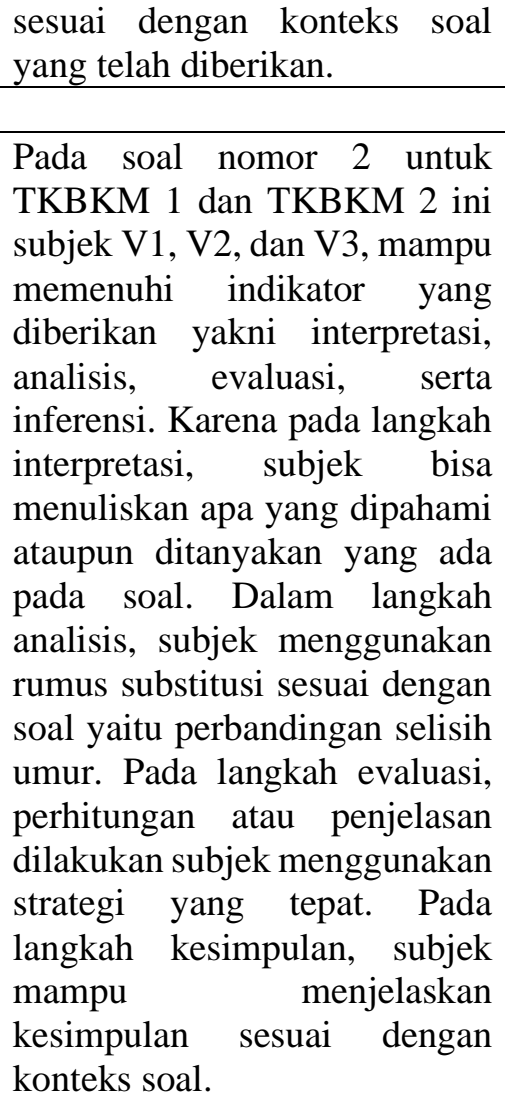

menjelaskan tetapi kurang tepat dalam hasil.

Pertanyaan nomor 2

Pada nomor 2 untuk soal Pada nomor 2 untuk TKBKM 1 TKBKM 1 dan 2 ini subjek A1, A2, dan A3, mampu memenuhi indikator yang diberikan yakni analisis, evaluasi, interpretasi, serta inferensi. Karena subjek mampu menuliskan apa yang ditanyakan ataupun dipahami yang ada pada soal, pada langkah interpretasi. Pada langkah analisis, menggunakan rumus substitusi yang sesuai dengan soal yaitu perbandingan selisih umur. Pada langkah evaluasi, perhitungan atau penjelasan dilakukan subjek menggunakan strategi yang tepat. Pada langkah evaluasi, Pada langkah kesimpulan, subjek mampu menjelaskan kesimpulan dengan benar dan tepat.

\section{Pertanyaan nomor 3}

Pada nomor 3 untuk TKBKM 1 dan TKBKM 2 ini subjek A1, A2, dan A3, mampu memenuhi indikator yang diberikan yakni evaluasi, analisis, interpretasi, serta inferensi. Karena subjek bisa menuliskan apa yang ditanyakan ataupun dipahami, pada langkah interpretasi. Pada langkah analisis, subjek menggunakan rumus luas persegi dan pemfaktoran aljabar bentuk selisih kuadrat berdasar pertanyaan yang ada pada soal dengan tepat. Pada langkah evaluasi, subjek memakai strategi yang sesuai pada Pada langkah kesimpulan, subjek menjelaskan kesimpulan sesuai dengan konteks soal. perhitungan atau penjelasan. dan 2 ini subjek $\mathrm{K} 1, \mathrm{~K} 2$, dan $\mathrm{K} 3$, mampu memenuhi indikator yang diberikan yakni analisis, evaluasi, interpretasi, serta inferensi. Karena subjek dapat menuliskan apa yang ditanyakan ataupun dipahami yang ada pada soal. Pada langkah analisis, subjek menggunakan rumus substitusi sesuai dengan soal yang diberikan yaitu perbandingan selisih umur. Pada langkah evaluasi, menggunakan strategi dalam perhitungan atau penjelasan dengan tepat. Pada langkah kesimpulan, mampu menjelaskan soal tersbeut dengan benar dan tepat sesuai konteks soal.
Pada nomor 3 untuk soal TKBKM 1 dan TKBKM 2 ini subjek K1, K2, dan K3, mampu memenuhi indikator kemampuan berpikir kritis yang diberikan yakni analisis, evaluasi, interpretasi, serta inferensi. Karena dalam langkah interpretasi, subjek mampu menuliskan apa yang dipahami ataupun ditanyakan. Subjek menggunakan rumus luas persegi dan pemfaktoran aljabar bentuk selisih kuadrat berdasar pertanyaan yang ada pada soal dengan tepat, pada langkah analisis. Pada langkah evaluasi, subjek menerapkan strategi yang sesuai dengan perhitungan atau penjelasan. Pada langkah kesimpulan, subjek mampu menjelaskan dengan tepat dan benar.

Pertanyaan nomor 4

Pada nomor 4 untuk TKBKM 1 dan TKBKM 2 ini subjek V1, V2, dan V3, mampu memenuhi indikator pada kemampuan berpikir kritis yang diberikan

$\begin{array}{llrll}\text { Pada soal nomor } 4 \text { untuk } & \text { Pada nomor 4 untuk soal } \\ \text { TKBKM 1 dan TKBKM 2 ini } & \text { TKBKM 1 dan TKBKM 2 ini } \\ \text { subjek A1, A2, dan A3, mampu } & \text { subjek K1, K2, dan K3, mampu } \\ \text { memenuhi indikator yang } & \text { memenuhi indikator yang } \\ \text { diberikan } & & \text { yaitu } & \text { diberikan yaitu interpretasikan }\end{array}$




\begin{tabular}{|c|c|c|}
\hline $\begin{array}{l}\text { yakni menginterpretasikan apa } \\
\text { yang ditanya ataupun } \\
\text { dipahami. Dalam langkah } \\
\text { analisis, menyusun model } \\
\text { matematika sesuai dengan soal } \\
\text { yaitu panjang sisi tongkat. Pada } \\
\text { langkah evaluasi, menggu- } \\
\text { nakan strategi yang tepat dalam } \\
\text { perhitungan atau penjelasan. } \\
\text { Pada langkah kesimpulan, } \\
\text { subjek mampu menjelaskan } \\
\text { kesimpulan sesuai dengan } \\
\text { konteks soal. }\end{array}$ & $\begin{array}{l}\text { menginterpretasikan apa yang } \\
\text { dipahai ataupun ditanyakan pada } \\
\text { soal tersebut. Pada langkah } \\
\text { analisis, dapat menyusun model } \\
\text { matematika sesuai dengan soal } \\
\text { yaitu panjang sisi tongkat. Pada } \\
\text { langkah evaluasi, subjek mampu } \\
\text { menggunakan strategi yang tepat } \\
\text { dalam perhitungan atau } \\
\text { penjelasan yang ada sesuai } \\
\text { konteks soal. Pada langkah } \\
\text { kesimpulan, subjek mampu } \\
\text { menjelaskan kesimpulan dengan } \\
\text { tepat. }\end{array}$ & $\begin{array}{l}\text { apa yang ditanya ataupun } \\
\text { dipahami. Pada langkah analisis, } \\
\text { mampu menyusun model } \\
\text { matematika sesuai dengan soal } \\
\text { yaitu panjang sisi tongkat. Pada } \\
\text { langkah evaluasi, mampu } \\
\text { menggunakan strategi yang } \\
\text { tepat dalam perhitungan atau } \\
\text { penjelasan dalam } \\
\text { menyelesaikan soal. Pada } \\
\text { langkah kesimpulan, subjek } \\
\text { mampu menjelaskan } \\
\text { kesimpulan dengan benar dan } \\
\text { tepat sesuai konteks soal. }\end{array}$ \\
\hline \multicolumn{3}{|c|}{ Pertanyaan nomor 5} \\
\hline $\begin{array}{l}\text { Untuk soal nomor } 5 \text { pada } \\
\text { TKBKM 1 dan TKBKM } 2 \text { ini } \\
\text { subjek V1, V2, dan V3, mampu } \\
\text { memenuhi indikator yang } \\
\text { diberikan yaitu interpretasikan } \\
\text { apa yang dipahami ataupun } \\
\text { ditanyakan yang ada pada soal. } \\
\text { Pada langkah analisis, subjek } \\
\text { dapat membuat model } \\
\text { matematika keliling serta luas } \\
\text { pergi panjang sesuai dengan } \\
\text { pertanyaan yang ada pada soal } \\
\text { dengan tepat. Pada langkah } \\
\text { evaluasi, mampu menggunakan } \\
\text { strategi yang tepat dalam } \\
\text { perhitungan atau penjelasan } \\
\text { dalam menjawab soal. Pada } \\
\text { langkah kesimpulan, } \\
\text { menjelaskan dengan benar dan } \\
\text { tepat sesuai konteks yang ada } \\
\text { pada soal. }\end{array}$ & $\begin{array}{l}\text { Soal nomor } 5 \text { pada subjek A1, } \\
\text { A2, dan A3, sudah mampu } \\
\text { memenuhi indikator yang } \\
\text { diberikan } \\
\text { menginterpretasikan apa yang } \\
\text { dipahami ataupun ditanyakan } \\
\text { pada pernyataan soal. Pada } \\
\text { langkah analisis, membuat } \\
\text { model matematika keliling dan } \\
\text { luas pergi panjang sesuai dengan } \\
\text { pertanyaan yang terdapat pada } \\
\text { soal dengan tepat. Pada langkah } \\
\text { evaluasi, subjek dapat } \\
\text { menggunakan cara dalam } \\
\text { menyelesaikan soal dengan tepat } \\
\text { dalam perhitungan atau } \\
\text { penjelasan. Pada langkah } \\
\text { kesimpulan, subjek mampu } \\
\text { menjelaskan kesimpulan sesuai } \\
\text { dengan konteks soal dengan } \\
\text { tepat. }\end{array}$ & $\begin{array}{l}\text { Soal nomor } 5 \text { pada TKBKM } 1 \\
\text { dan TKBKM } 2 \text { ini subjek K1, } \\
\text { K2, dan K3, mampu memenuhi } \\
\text { indikator yang diberikan yaitu } \\
\text { pada langkah interpretasi, } \\
\text { subjek dapat menuliskan apa } \\
\text { yang diketahui ataupun } \\
\text { ditanyakan yang ada pada soal. } \\
\text { Pada langkah analisis, subjek } \\
\text { dapat membuat model } \\
\text { matematika keliling dan luas } \\
\text { pergi panjang sesuai dengan } \\
\text { pertanyaan yang terdapat pada } \\
\text { soal dengan tepat. Pada langkah } \\
\text { evaluasi, subjek mampu } \\
\text { menggunakan strategi yang } \\
\text { tepat dalam perhitungan atau } \\
\text { penjelasan untuk menjawab } \\
\text { soal. Pada langkah kesimpulan, } \\
\text { subjek mampu menjabarkan } \\
\text { dengan benar dan tepat sesuai } \\
\text { soal yang diberikan. }\end{array}$ \\
\hline
\end{tabular}

Berdasarkan tabel 5 di atas, sejalan dengan Permana (2020) menyebutkan bahwa gaya belajar visual paling memberipengaruh pada signitfikan terhadap kemampuan penyelesaian masalah siswa. Apipah et al., (2018) juga menyebutkan bahwa siswa bergaya belajar visual mempunyai kemampuan koneksi matematis yang lebih baik jika di banding dengan siswa bergaya belajar kinestetik dan auditori. Indraswari et al., (2018) dalam penelitiannya menyebutkan bahwa siswa bergaya belajar kinestetik dan visual menuliskan penyelesaikan masalah matematika menggunakan symbol/kalimat matematika secara umum, sementara siswa bergaya belajar auditori menuliskan penyelesaian dalam bentuk kalimat. Setiana \& Purwoko (2020) menganalisis kemampuan berpikir kritis berdasar gaya belajar yang menunjukkan bahwa siswa yang bergaya belajar visual memiliki kategori sangat baik, dalam kemampuan berpikir kritis, siswa yang bergaya belajar kinestetik mempunyai kemampuan berpikir kritis dengan kategori baik, dan siswa yang bergaya belajar auditori memiliki kemampuan berpikir kritis 
dengan kategori cukup. Hasil penelitian ini berbeda dengan penelitian dari Amir (2015) yang memaparkan bahwa siswa bergaya belajar kinestetik mempunyai proses berpikir kritis yang lebih baik dibanding siswa bergaya belajar auditori dan visual.

\section{KESIMPULAN}

Dari hasil penelitian diperoleh kesimpulan: (1) Siswa yang bergaya belajar visual mempunyai kemampuan berpikir kritis matematis dengan kategori sangat baik, siswa tersebut mampu memenuhi indikator interpretasi, analisis, evaluasi, inferensi; (2) siswa yang bergaya belajar auditorial memiliki kemampuan berpikir kritis matematika dengan kategori baik, siswa mampu memenuhi indikator analisis, evaluasi, inferensi, tetapi untuk interpretasi dalam menjabarkan masih kurang lengkap; dan (3) siswa yang bergaya belajar kinestetik mempunyai kemampuan berpikir kritis matematis dengan kategori cukup baik, siswa belum mampu mencapai indikato analisis dan evaluasi. Kesimpulannya, siswa yang bergaya belajar visual dengan kategori sangat baik dalam kemampuan berpikir kritis matematis, karena lebih mampu menjelaskan objek matematika yang baik secara visual sebelum menyelesaikan permasalahan matematika. Namun dalam hal ini, siswa bergaya belajar auditorial dan kinestetik tetap mampu mempunyai potensi mengembangkan kemampuan berpikir kritis matematis.

\section{REFERENSI}

Amir, M. F. (2015). Proses Berpikir Kritis Siswa Sekolah Dasar Dalam Memecahkan Masalah Berbentuk Soal Cerita Matematika Berdasarkan Gaya Belajar. Jurnal Math Educator Nusantara, 01(02), 159-170.

Apipah, S., Kartono, \& Isnarto. (2018). An Analysis Of Mathematical Connection Ability Based On Student Learning Style On Visualization Auditory Kinesthetic (VAK) Learning Model With SelfAssessment. Journal of Physics: Conference Series, 983(1). https://doi.org/10.1088/17426596/983/1/012138

Basri, H., Purwanto, As'ari, A. R., \& Sisworo. (2019). Investigating Critical Thinking Skill Of Junior High School In Solving Mathematical Problem. International Journal of Instruction, 12(3), 745758. https://doi.org/10.29333/iji.2019.12345a

Brown, H. D. (2000). Principles Of Language Learning And Teaching.

Cahyana, U., Kadir, A., \& Gherardini, M. (2017). Relasi Kemampuan Berpikir Kritis Dalam Kemampuan Literasi Sains pada Siswa Kelas IV Sekolah Dasar. 14-22. file://C:/Users/ASUS/AppData/Local/Temp/1323-3043-1-SM.pdf

DePorter, B., \& Hernacki, M. (2011). Quantum Learning: Membiasakan Belajar Nyaman dan Menyenangkan.

Facione, P. a. (2015). Critical Thinking: What It Is and Why It Counts. In Insight assessment (Issue ISBN 13: 978-1-891557-07-1.). (https://www.insightassessment.com/CT-Resources/TeachingFor-and-About-Critical-Thinking/Critical-Thinking-What-It-Is-and-Why-It-Counts/Critical- 


\section{Thinking-What-It-Is-and-Why-It-Counts-PDF)}

Fadhilah, N. (2018). Analisis Gaya Belajar Peserta Didik Dalam Pembelajaran Tematik Di Kelas II C MI Pembangunan UIN Jakarta.

Hamidon, nurul aida binti. (2015). Study On Students Learning Style According To Gender Factor. Journal of Culture, Society and Development, 8(2002), 20-22.

Harjo, B., Kartowagiran, B., \& Mahmudi, A. (2019). Development Of Critical Thinking Skill Instruments On Mathematical Learning High School. International Journal of Instruction, 12(4), 149-166. https://doi.org/10.29333/iji.2019.12410a

Indraswari, N. F., Budayasa, I. K., \& Ekawati, R. (2018). Algebraic Reasoning in Solving Mathematical Problem Based on Learning Style. Journal of Physics: Conference Series, 947(1). https://doi.org/10.1088/1742-6596/947/1/012061

Ishartono, N., Faiziyah, N., Sutarni, S., Putri, A. B., Fatmasari, L. W. S., Sayuti, M., Rahmaniati, R., \& Yunus, M. M. (2021). Visual, Auditory, and Kinesthetic Students: How They Solve PISA-Oriented Mathematics Problems? Journal of Physics: Conference Series, 1720(1). https://doi.org/10.1088/1742-6596/1720/1/012012

Jamulia, J. (2018). Identifying Students Learning Style Preferences At Iain Ternate. International Journal of Education, 10(2), 121-129. https://doi.org/10.17509/ije.v10i2.1631

Kane, S. N., Mishra, A., \& Dutta, A. K. (2016). Analysis of Mathematics Critical Thinking Students in Junior High School Based on Cognitive Style. Journal of Physics: Conference Series, 755(1). https://doi.org/10.1088/1742-6596/755/1/011001

Kemendikbud. (2016). Peraturan Menteri Pendidikan Dan Kebudayaan Nomor 20 Tahun 2016 (pp. 1$8)$.

Kowiyah. (2016). Peningkatan Kemampuan Berpikir Kritis dalam Pemecahan Masalah Matematis Menggunakan Pendekatan Open Ended. 1(2), 67-74.

Kurniati, A., \& Sari, A. W. (2019). Analisis Gaya Belajar Siswa Pada Mata Pelajaran Bahasa Indonesia Kelas V. Jurnal Pendidikan Dasar Perkhasa, 5(April), 87-103. http://jurnal.stkippersada.ac.id/jurnal/index.php/JPDP/

Mar'ah, A. (2015). Gaya Belajar Dan Faktor Pengaruhnya Terhadap Pencapaian Prestasi Belajar Ipa Terpadu Siswa Kelas VIII Mts Sultan Fatah Gaji Guntur Demak Tahun Pelajaran 2015/2016.

Maula, F. Q. (2017). Gaya Belajar Siswa Kelas VIII SMP Negri 1 Boja pada Mata Pelajaran IPA Biologi.

Mawaddah, Ahmad, A., \& Duskri, M. (2018). Gender Differences Of Mathematical Critical Thinking Skills Of Secondary School Students. Journal of Physics: Conference Series, 1088. https://doi.org/10.1088/1742-6596/1088/1/012054

Mayaningtyas, D. (2016). Analisis Kemampuan Berpikir Kritis Pada Resource Based Learning Ditinjau Dari Gaya Belajar Siswa Sma Kelas X.

Muhtadi, D., Supratman, \& Hermanto, R. (2019). The Students' Mathematical Critical Thinking Process 
Reviewed From The Cognitive Style. Journal of Physics: Conference Series, 1188(1). https://doi.org/10.1088/1742-6596/1188/1/012082

Nugroho, G. N., \& Riyanto, O. R. (2019). Mathematical Critical Thinking Ability Reviewed From SelfEfficacy in Discovery Learning. Eduma: Mathematics Education Learning and Teaching, 8(1), 25-32. https://doi.org/10.24235/eduma.v8i1.4593

Özerem, A., \& Akkoyunlu, B. (2015). Learning Environments Designed According to Learning Styles and Its Effects On Mathematics Achievement. Eurasian Journal of Educational Research, 15(61), 61-80. https://doi.org/10.14689/ejer.2015.61.4

Paul, B. R. W., \& Elder, L. (2002). Critical Thinking : Tools for Taking Charge of Your Professional and Personal Life.

Peraturan Menteri Pendidikan Dan Kebudayaan Republik Indonesia Nomor 22 Tahun 2016, Kemendikbud $\quad$ RI 1 (2016). http://luk.tsipil.ugm.ac.id/atur/bsnp/Permendikbud222016SPDikdasmen.pdf

Permana, R. I. (2020). Influence of Visual, Auditory, Kinesthetic Learning Style on The Ability of Troubleshooting E-Learning-Based Math. Journal of Education and Practice, 11(18), 182-187. https://doi.org/10.7176/jep/11-18-20

Peter, E. E. (2012). Critical Thinking: Essence For Teaching Mathematics and Mathematics Problem Solving Skills. African Journal of Mathematics and Computer Science Research, 5(3), 39-43. https://doi.org/10.5897/ajmcsr11.161

Purwanto, W. R., Waluya, S. B., Rochmad, \& Wardono. (2020). Analysis Of Mathematical Critical Thinking Ability In Student Learning Style. Journal of Physics: Conference Series, 1511(1). https://doi.org/10.1088/1742-6596/1511/1/012057

Rahmayani, I. (2017). Pengaruh Gaya Belajar Terhadap Prestasi Belajar Mahasiswa Pendidikan Kedokteran Universitas Hasanuddin Angkatan 2016.

Setiana, D. S., \& Purwoko, R. Y. (2020). Analisis Kemampuan Berpikir Kritis Ditinjau Dari Gaya Belajar Matematika Siswa. Jurnal Riset Pendidikan Matematika, 7(2), 163-177.

Setiawan, W. Y., Rosita, N. T., \& Putra, B. Y. G. (2020). The Influence Of Learning Styles On Students' Mathematical Critical Thinking Skills In Solving Trigonometric Problems. Journal of Physics: Conference Series, 1657(1). https://doi.org/10.1088/1742-6596/1657/1/012015

Singh, L., Govil, P., \& Rani, R. (2018). Learning Style Preferences Among Secondary School Students. International Journal of Recent Scientific Research, 6(May 2015), 3924-3928. https://doi.org/10.13140/RG.2.2.36377.72803

Su, H. F. H., Ricci, F. A., \& Mnatsakanian, M. (2016). Mathematical Teaching Strategies: Pathways to Critical Thinking and Metacognition. International Journal of Research in Education and Science, 2(1), 190-200. https://doi.org/10.21890/ijres.57796

Sugiyono. (2017). Metode Penelitian Kuantitatif, Kualitatif, dan R\&D. In cetakan ke-26 (p. 274).

Susanti, E., \& Hartono. (2019). An Analysis Mathematical Problem Solving and Mathematical Critical 
Thinking Skills of Junior High School Students. Journal of Physics: Conference Series, 1320(1). https://doi.org/10.1088/1742-6596/1320/1/012071

Umar, W. (2017). Constructing Means Ends Analysis Instruction to Improve Students' Critical Thinking Ability and Mathematical Habits of Mind Dispositions. International Journal of Education and Research, 5(2), 261-272.

Widana, I. W. (2018). Higher Order Thinking Skills Assessment towards Critical Thinking on Mathematics Lesson. International Journal of Social Sciences and Humanities (IJSSH), 2(1), 24 32. https://doi.org/10.29332/ijssh.v2n1.74 